\title{
Plant Species Numbers Predicted by a Topography-based Groundwater Flow Index
}

\author{
Ursula Zinko, ${ }^{1}$ Jan Seibert, ${ }^{2,3}$ Mats Dynesius, ${ }^{1}$ and Christer Nilsson ${ }^{1}$
}

\footnotetext{
${ }^{1}$ Landscape Ecology Group, Department of Ecology and Environmental Science Umea University, SE-901 87, Umeå, Sweden; ${ }^{2}$ Department of Environmental Assessment, Swedish, University of Agricultural Sciences, Box 7050, SE-750 07, Uppsala, Sweden; ${ }^{3}$ Department of Physical Geography and Quaternary Geology,, Stockholm University, S6-106 91, stockholm, Sweden
}

\begin{abstract}
The lack of a clear understanding of the factors governing the often-great variation of species numbers over entire landscapes confounds attempts to manage biodiversity. We hypothesized that in a topographically variable boreal forest landscape the availability of shallow groundwater is a major determinant of plant species numbers. We then developed a topographically derived hydrologic index based on multidirectional flow algorithms to account for the variation in availability of such groundwater in the landscape. We found a positive correlation between species numbers of vascular plants in plots ranging from 0.01 to $200 \mathrm{~m}^{2}$ and the hydrologic index. Generally, the landscape was relatively dry and species-poor, but interspersed patches with shallow groundwater had high species numbers and high proportions of regionally uncommon plant species. The index explained $30 \%$ of the variation in vascular plant
\end{abstract}

number and correlated quite well $\left(r_{\mathrm{S}}=0.50\right)$ with groundwater level, but not as well with a community $\mathrm{H}^{+}$concentration value (instead of community $\left.\mathrm{pH}, r_{\mathrm{s}}=-0.31\right)$, based on species composition. In addition, we found a very strong correlation between species number and the community $\mathrm{H}^{+}$concentration value $\left(r_{\mathrm{s}}-0.84\right)$. The hydrologic index is a useful tool for the identification of spatial of species number patterns across entire landscapes. This is an important step in identifying the areas most in need of protection or restoration, designing survey techniques, and understanding the fundamental processes that control the spatial distribution of species.

Key words: species richness; wetness index; boreal forest; vascular plants; slope; nestedness; scale dependence.

\section{INTRODUCTION}

Recent studies suggest that the processes determining species richness vary with spatial scale (Zobel 1997; Crawley and Harral 2001; Whittaker and others 2001). The understanding of such var-

Received 2 September 2003; accepted 10 February 2004; published online 28 June 2005.

*Corresponding author: e-mail: ursula.zinko@emg.umu.se iation, and especially the processes that govern species richness patterns over landscapes and regions, has become increasingly important as the deterioration of the world's natural habitats continues to escalate. This is true from a protection as well as a restoration standpoint, and the need for knowledge becomes acute when conservation management is combined with other kinds of land use. Such situations of optimized multiple use could be termed "normative landscapes" — that is, landscapes maintaining the highest level of ecological functioning possible within the economic 
and social constraints at hand (Stanford 1997; Williams and others 1999).

We considered the common case of a boreal forest landscape where commercial forestry is the dominant land use and where, for that particular reason, only a small proportion of the landscape could be considered for conservation management. In such landscapes, especially in cases where the topography is variable, the spatial variation of groundwater availability is an important factor affecting both tree growth and vegetation composition (Cajander 1926; Ebeling 1978). Riparian forests have a constant supply of groundwater close to the surface. In boreal areas, these riparian forests have considerably more vascular plant species than upland forests. For example, two to three times higher species densities of bryophytes (Dynesius 2001) and vascular plants (M. Dynesius and C. Nilsson unpublished) were found in riparian forests along small streams in boreal Sweden than in randomly chosen upland forests. Unlike riparian forests, groundwater flow only intermittently influences most vegetation types of boreal forests. We hypothesized that a topographically based hydrologic index could be used to predict variations in the influence of groundwater flow and thus species numbers over entire landscapes. If such a prediction becomes successful, it would provide a tool that could replace much laborious field work.

Several hydrologic indices based partially on topographic variables have been produced to predict the distribution of vegetation types (Moore and others 1991; Iverson and others 1997; Ostendorf and Reynolds 1998; Dorner and others 2002). Some studies have partially used topographic variables to predict species richness. In Rhode Island, USA, the topographic variables slope and aspect explained only $0.04 \%$ and $0.02 \%$, respectively, of the variation in vascular plant species richness (Nichols and others 1998), whereas soil drainage explained 53\%. Hutchinson and others (1999) used an Integrated Moisture Index based on three topographic variables and one soil variable-a slope aspect shading index, water flow accumulation, hillslope curvature, and total water-holding capacity-which explained $35 \%$ of the variation in species number of vascular plants in a mixed oak forest in Ohio, USA. Species number increased from dry to mesic habitats; however, moist and wet stands were not included. Chipman and Johnson (2002) found that hillslope position, being a topographic variable, together with surficial geology and an interaction term of canopy basal area and timesince-fire explained $52 \%$ of the variation in vas- cular plant species number in the boreal forest of Saskatchewan, Canada. Skov and Svenning (2003) modeled understory species diversity in a managed forest in eastern Jutland, Denmark. The model, based on three maps of soil, topography, and forest stands, together with distribution data from a floristic survey, explained $6 \%$ of the variation of observed species numbers.

In this study, we set out to test how well topography by itself can predict vascular plant species densities from dry to wet forests. We therefore kept the model simple, using only elevation above sea level as the input variable in an algorithm, partially developed by us, to produce a topographic wetness index. We hypothesized that the wetness index can predict level and flow groundwater level and flow, which in turn influences species numbers directly or indirectly, because areas with groundwater discharge in boreal forests have higher base saturation and $\mathrm{pH}$ than upland recharge areas (Giesler and others 1998).

\section{MeTHODS}

\section{Topographic Wetness Index}

The primary control of soil moisture in boreal forest landscapes is usually topography, because precipitation and evaporation are relatively uniform across space at the scale of interest. Variation of surficial geology can be assumed to be of minor importance, because glacial till covers most of these landscapes (see also O'Loughlin 1986; Wood and others 1988; Økland and Eilertsen 1994; Yeakley and others 1998; Western and others 1999). These soils have in general a high infiltration capacity and show a systematic variation of hydraulic conductivities decreasing with depth. The groundwater table is usually rather close to the surface and thus groundwater flow can be assumed to follow the topography. The local upslope area-that is, the area from which water is assumed to drain through a certain location-is the most important variable determining groundwater flow, because it provides a measure of the amount of water flowing through this location. Together with the slope as a measure of how quickly water drains from the location, the topographic wetness index $\ln (a / \tan \beta)$ can be computed. This index can be derived theoretically to predict the local depth to groundwater (Beven and Kirkby 1979). Iverson and others (1997) and Hutchinson and others (1999) used a one-directional flow algorithm to compute upslope areas for their Integrated Moisture Index. In this study, we instead used a multidirectional flow algorithm for 
the computation of a Topographic Wetness Index (TWI).

The TWI was computed from the upslope area per unit contour length $(a)$ which indicates the amount of water flowing toward a certain location, and the local slope $(\tan \beta)$, which is a measure of the drainage from a place, as $\ln (a / \tan \beta)$. This index can be calculated from gridded elevation data using various algorithms, which differ mainly in the way the upslope area is computed (Wolock and McCabe 1995). Multidirectional flow algorithms tend to give more realistic-looking spatial patterns (Wolock and McCabe 1995) than single-directional flow algorithms where the flow is concentrated in distinct lines. One problem of a single-directional flow algorithm, where the area from one cell is routed into the steepest of its eight neighboring cells, is that the steepest gradient might actually fall between two of the eight cardinal and diagonal directions. Tarboton (1997) tackled this problem by using triangular facets, thus enabling water to flow in more than eight discrete directions. The method we used in this study combines the advantages of the multidirectional flow algorithm (Quinn and others 1991) with the use of triangular facets (J. Seibert unpublished). The area accumulated at a certain cell was distributed among the neighboring cells by first calculating all downslope directions from the cell and then selecting those directions where the surface perpendicular to the flow direction was concave. Around the midpoint $(\mathrm{M})$ of the pixel, eight planar triangular facets were constructed with midpoints $\left(\mathrm{P}_{1}\right.$ and $\left.\mathrm{P}_{2}\right)$ of two adjacent neighboring pixels (Figure 1). For each of these local planes, the direction of the steepest gradient was computed. If this steepest direction from $M$ was outside the $45^{\circ}(\pi / 4$ radian) angle range of the particular triangular facet (that is, not between the vectors pointing from $M$ toward $P_{1}$ and $P_{2}$, respectively), the direction with the steeper gradient, of the two directions toward $\mathrm{P}_{1}$ or $\mathrm{P}_{2}$, was used as the steepest direction. After computing the steepest direction for all eight triangular facets, the directions with the steep lest gradient compared to both adjacent facets were considered the concave local outflows. Flow was then distributed to these local outflows using a weighting based on the gradients.

Our flow algorithm also differed from other algorithms on two additional points. First, streams were assumed to start when the accumulated area exceeded a certain threshold area (set to 15,000 $\mathrm{m}^{2}$ ). The accumulated area of a "stream cell" was routed downslope as "stream area" and not considered in the calculation of $a$ in any downslope

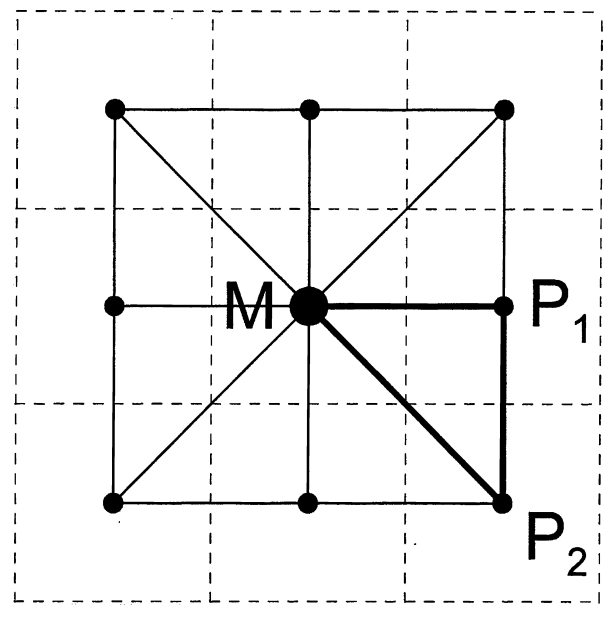

Figure 1. Procedure used to compute the upslope area. Around the midpoint $(\mathrm{M})$ of the pixel in question, eight planar triangular facets were constructed with midpoints (P1 and P2) of two adjacent pixels. The slope direction of each of these triangular facets was then calculated. Area was routed to all facets that were down-slope from the midpoint and had a steeper slope than both adjacent facets (that is, maximal four directions).

cell, because the basic assumptions that underlie the TWI do not hold when there is a stream. Second, we treated cells without any adjacent downslope cell, or that is depressions-differently from most algorithms, where these so-called sinks are "filled" with water before the index is calculated. Instead, we considered depressions as real topographic features and continued the search for downslope cells using all cells located $2,3, \ldots$ cells away, until at least one downslope cell was found and the area was routed to this/these cell(s) (Rodhe and Seibert 1999). Finally, we replaced the commonly used local gradient, $\tan \beta$, by a downslope index, $\tan \beta_{\mathrm{d}}$ (Hjerd (2004)). This index is calculated as $d / l$ where $L_{\mathrm{d}}$ is the distance to the nearest cell having a height at least $d$ length units (here set to 2 $\mathrm{m})$ below the cell. This index takes downslope topography into account, which might impede or enhance local drainage. The idea is that the downslope index might be a better estimate of the slope of the groundwater table than the local gradient of the surface, especially in locations with a strong profile curvature.

High values of TWI indicate high groundwater levels but do not necessarily coincide with locations of high groundwater flow. The amount of flow would be better expressed by the values of the upslope area, $a$, but this flow might not always correspond to near-surface groundwater. High values of TWI, on the other hand, can indicate both 


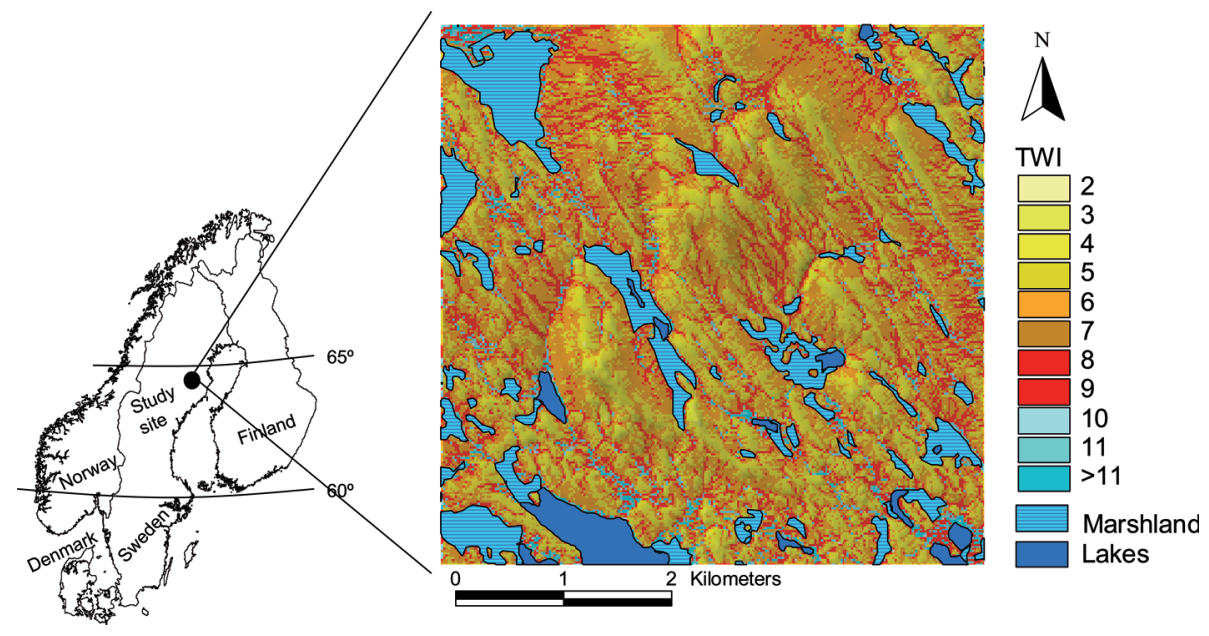

Figure 2. Location of the study site in northern Sweden and map of the $25-\mathrm{km}^{2}$ study area showing the results of the hydrologic classification. * TWI $=$ Topographyic Wetness Index (TWI) Each $20 \times 20 \mathrm{~m}$ pixel was assigned a TWI value. high flow and stagnant groundwater (because of low gradients). In our case, however, the values of TWI for each plot were determined mainly by the variation of the contributing areas $a[r=0.89, P<$ $0.0001, n=88$ for the correlation between TWI and $\ln (a)]$. Therefore, similar results were obtained for TWI and $\ln (a)$, but we used TWI because the correlation with species number was somewhat higher for TWI than for $\ln (a)$.

We investigated all hydrologic conditions in the landscape from hilltops to areas where the groundwater coincides with or exceeds the ground surface level during the vegetation period. Seepage areas are often quite small and can be missed on low-resolution maps. We therefore used a $20-\mathrm{m}$ grid supported by new elevation data produced for this study by the National Land Survey of Sweden. The elevation of the ground (meters above sea level) was determined for every $20 \mathrm{~m}$ in the $25-\mathrm{km}^{2}$ study area from aerial photographs using the Zeiss PlaniComp analytic stereo instrument with the Microstation program (accuracy of $\pm 0.7 \mathrm{~m}$ ). The standard 50-m grid of Swedish topographic maps was considered too coarse (Rodhe and Seibert 1999; Quinn and others 1995), but it was computed for comparison.

\section{Study Area and Sampling of Sites}

The $25-\mathrm{km}^{2}$ study area was located in the county of Västerbotten, in boreal Sweden $\left(64^{\circ} 33^{\prime} \mathrm{N}, 19^{\circ} 35^{\prime} \mathrm{E}\right)$ (Figure 2). The temperature sum during the vegetation period (the days during a year with mean temperature greater than $+5^{\circ} \mathrm{C}$ ) is within the range of $750-900^{\circ} \mathrm{C}$ and both the precipitation and evaporation during the same period are within the range of $300-350 \mathrm{~mm}$ (data from the Swedish Survey of Forest Soils and Vegetation). The elevation of the area is $220-400 \mathrm{~m}$ above sea level. The bedrock is acidic (mainly granites, with some intrusions of metasedimentary rocks and amphibolites). The soil consists mainly of glacial till, but peat covers many of the depressions (Figure 2). The vegetation is mainly forest, dominated by Pinus sylvestris or Picea abies. The forest developed from selective cutting of large trees from the $19^{\text {th }}$ up to the mid $20^{\text {th }}$ century, to clear-cutting of entire stands, drainage, planting, and even the introduction of exotics (Pinus contorta and Abies sp.). Today a fragmented forest with clear-cut areas, young plantations with native and exotic tree species, and older semi-natural forest patches covers the area.

The entire $25-\mathrm{km}^{2}$ area yielded TWI values ranging between 2 and 18 (Figure. 2). We restricted the study to forest land having TWI values no higher than 11.5. Higher TWI mostly represented treeless marshlands, streams, and lakes. For the sampling procedure, TWI values were classified so that TWI $2=1.50-2.49$, TWI $3=2.50-3.49$, and so on. Quadratic plots measuring $200 \mathrm{~m}^{2}$ were to the center of eighty-eight 20-m cells of the digital elevation data. the selection of these cells was random, but stratified according to TWI values so that study plots were evently distributed along the TWIgradient. The plots were located in the field using a differential global positioning system (DGPS) receiver. In total, we analyzed 88 plots, in 88 grid cells. To evaluate the influence of plot size, we also located subplots measuring $0.01,0.25$, and $1 \mathrm{~m}^{2}$, respectively, from the center of each $200-\mathrm{m}^{2}$ plot.

\section{Field Sampling and Data Analysis}

We recorded the presence of all vascular plant species at the four plot scales during July 1999, and analyzed the relationships between species number and TWI using linear least square regression. To explore the relationship between species number 
Table 1. Mean, Range and Spearman's Rank Correlation Coefficients for the Relationship between Species Number and the Environmental Variables Used in the Multiple Regression Model

\begin{tabular}{|c|c|c|c|c|}
\hline Variable & Mean & Range & $r_{\mathrm{s}}^{a}$ & Substrate Frequency $(\%)^{\mathrm{b}}$ \\
\hline Species numbers & 23.23 & $8-48$ & & \\
\hline TWI & 6.96 & $2.95-11.34$ & $0.56 * * *$ & \\
\hline Light ( $\mu$ Einstein) & 65.13 & $8.18-159.54$ & NS & \\
\hline Altitude (m a.s.l.) & 299.15 & $225-425$ & $0.23 *$ & \\
\hline Tree diameter $(\mathrm{m})^{c}$ & 16.06 & $0-29.45$ & NS & \\
\hline Substrate number & 2.32 & $1-4$ & NS & \\
\hline Aspect $\left({ }^{\circ}\right)^{\mathrm{d}}$ & 173 & $5-343$ & NS & \\
\hline \multicolumn{5}{|l|}{ Basal area $\left(\mathrm{m}^{2} / \mathrm{ha}\right)$} \\
\hline Total & 12.19 & $0-37.39$ & NS & \\
\hline Pinus sylvestris & 7.53 & $0-33.05$ & $-0.38 * * *$ & \\
\hline Picea abies & 2.06 & $0-20.90$ & $0.25^{*}$ & \\
\hline Deciduous trees & 2.60 & $0-19.99$ & $0.40 * * *$ & \\
\hline \multicolumn{5}{|l|}{ Substrate types } \\
\hline Bedrock & 2.5 & $0-80$ & NS & 6 \\
\hline Boulders & 55.6 & 0-99 & NS & 89 \\
\hline Sandy till & 1.4 & $0-60$ & NS & 9 \\
\hline Fine sandy till & 16.7 & 0-94 & NS & 59 \\
\hline Silty till & 2.0 & $0-70$ & NS & 14 \\
\hline Peat $10-30 \mathrm{~cm}$ & 18.0 & $0-100$ & $0.34 * *$ & 39 \\
\hline Peat $>30 \mathrm{~cm}$ & 14.6 & $0-100$ & $0.24^{*}$ & 28 \\
\hline \multicolumn{5}{|c|}{$\begin{array}{l}\text { Topographic Wetness Index (TWI), altitude and basal area of Pinus sylvestris, were included (in that order) in the multiple regression model. Substrate numbers were not } \\
\text { included in the multiple regression analysis, but analyzed using univariate analysis of variance. } n=88 \\
{ }^{a} \text { Spearman's rank correlation coefficients for the relationship between species numbers and the environmental variables. }{ }^{*} P<0.05, * * P<0.01, * * * P<0.001, N S=P>0.05 \text {, } \\
{ }^{c} \text { Percentage of number of plots where the different substrate types were found. } \\
\text { cMean tree diameter for the five largest trees per plot. }\end{array}$} \\
\hline
\end{tabular}

and TWI more closely, we performed a locally weighted regression scatterplot smoothing, or LOWESS regression (Trexler and Travis 1993), using $50 \%$ of the total number of points to calculate each LOWESS regression point in Sigma Plot Version 7-101 (SPSS Inc, Chicago, Iuinois) We also analyzed the relationship between number of uncommon species and TWI. Uncommon species were those not classified as regionally common by Krok and Almquist (2001).

All environmental variables except light were estimated during 1999 at the 200-m² level. By using a soil probe sampler, we estimated the percentage cover of substrate types (peat more than 30 cm deep, peat 10-30 cm deep, bedrock, boulders, and five different till types) (Table 1) for the entire $200-\mathrm{m}^{2}$ plots. Substrate heterogeneity was calculated as the number of different substrate types. Altitude was obtained from the digital elevation data provided by the National Land Survey of Sweden. We noted aspect in the field, taking a somewhat larger area into consideration, not only the very local slope exactly at the point of interest. We then calculated a transformed aspect, which is a function of $\cos \left(\mathrm{A}_{\max }-\mathrm{A}\right)+1$ (Beers and others 1966), where $A$ is the slope aspect in radians measured clockwise from north and $A_{\max }$ is the direction assumed to have most impact on species number and is given the highest value equal to 2.00. We assigned southwest-facing slopes the maximum value of 2.00 because maximal variation in plant communities has been found on southwest-facing slopes in previous studies (Heikkinen 1991). Mean tree diameter for the five largest trees was used as an indicator of stand age. We measured tree diameter of all trees larger than $5 \mathrm{~cm}$ diameter at breast height and calculated basal areas of $P$. sylvestris, $P$. abies, and deciduous trees, respectively, for each plot, as well as the total basal area for all tree species. Light was measured with a light sensor in $\mu$ Einstein on 16 evenly distributed points $0.5 \mathrm{~m}$ above the ground (above the understory) in the $200-\mathrm{m}^{2}$ plots between $11 \mathrm{AM}$ and $3 \mathrm{PM}$ (daylight savings time) during four completely cloud-free days in the year 2000 (6 and 26-28 July).

For the $200-\mathrm{m}^{2}$ plots, we constructed a model to predict species number using the forward stepwise procedure in a linear least-square regression with 
TWI, substrate composition (each substrate type was entered as a separate variable), light, altitude, aspect, basal area (total basal area or basal area divided into three categories), and stand age as independent variables (Table 1). Because number of substrates is an ordinal variable, the relationship between species number and number of substrates was analyzed using univariate analysis of variance, with the number of substrates as the random factor, and the other variables (Table 1) as covariates.

To validate the accuracy of the wetness index and to relate groundwater level to other environmental variables, we measured groundwater level and installed wells consisting of $0.75-\mathrm{m}$ plastic tubes, as closely as possible to the center in of the $200-\mathrm{m}^{2}$ plots, to a depth of $0.70 \mathrm{~m}$. In one plot, the cover of bedrock and boulders made it impossible to install a tube. For the same reason, all tubes could not be inserted down to $0.7 \mathrm{~m}$. The length of the tube restricted observations of groundwater levels below $0.7 \mathrm{~m}$, but this depth was considered sufficient to capture the most important groundwater variations and to comprise the range from which most water uptake by boreal plants usually takes place (Bishop and Dambrine 1995). When we inserted a smaller tube into the installed tube and blew into it gently, the sound of bubbles indicated where the inserted tube hit the water level. Groundwater level was measured four times (once a month) during the vegetation period (June to September) in 2001. During analysis, we excluded all 37 plots where the tube could not be inserted down to $0.7 \mathrm{~m}$ and where no water was recorded. We correlated both mean and September groundwater levels (when the overall water level was highest) with TWI, community $\mathrm{H}^{+}$concentration, and species density in the $200-\mathrm{m}^{2}$ plots using Spearman's rank correlation $\left(r_{\mathrm{s}}\right)$. For the seven plots with groundwater levels lower than $0.7 \mathrm{~m}$ in September, the level was set to $0.7 \mathrm{~m}$.

To make a gross assessment of the difference in species pool size for different TWI levels, we pooled the species lists of groups of plots with similar TWI (eight $200-\mathrm{m}^{2}$ plots, totaling $1.6 \mathrm{ha}$ ). First, the 88 plots were sorted by increasing TWI. We then calculated the total number of different species in eight consecutive plots along the TWI gradient, starting with the eight plots (plots 1-8) with the lowest TWI values, continuing with plots $2-9$, and so on up to the last plots (81-88), which had the highest TWI. We also calculated the fraction of each of the 10 TWI classes in the entire study area (25 $\mathrm{km}^{2}$ ) by summing the $400 \mathrm{~m}^{2}$ pixels.

We asked whether there is a high turnover of plant species along the wetness gradient, or whether there is a nested pattern going from dry, species-poor areas to wetter, species-rich ones. A perfectly nested species distribution means that species in plots with less species richness are mere subsets of species in more species-rich plots (Patterson and Atmar 1986). When species richness increases, species are added only to the total species list. No species found on species-poor sites are lost in the species-rich sites. We tested if the species distribution was nested by creating a species-by-site matrix, with sites in columns and species in rows. The species were sorted by decreasing frequency and the sites by decreasing species numbers. A perfectly nested matrix would have all matrix cells filled toward the upper left corner of the matrix. We then calculated the discrepancy for the matrix, which is the number of species occurrences that need to be shifted to produce a perfectly nested matrix from the observed matrix (Brualdi and Sanderson 1999). To assess if the observed discrepancy significantly deviated from randomness, we compared it with 1,000 random matrices under the RANDNEST null model (Jonsson 2001) in a Monte Carlo test. The species in these matrices are randomly dispersed, with the sole constraint of having the same mean frequency as in the observed data set. We then made the formal significance test by assuming normal distribution of the discrepancy for the 1,000 random null matrices and calculating the probability of the observed discrepancy against this normal distribution (using the NORMDIST function in Excel).

To test indirectly how TWI relates to soil $\mathrm{pH}$, we constructed a community $\mathrm{H}^{+}$concentration variable (instead of using $\mathrm{pH}$, because its logarithmic nature) from the species composition at each site. We used independently derived soil $\mathrm{H}^{+}$concentrations for regionally sampled sites where species included in our study grow. We obtained the data from the Swedish Survey of Forest Soils and Vegetation. The $\mathrm{pH}$ measurements had been made during 1994-97. We included 736 circular plots with a radius of $5.64 \mathrm{~m}$ that were situated within a circle with a $200-\mathrm{km}$ radius from the center of our study area. In the survey, a humus sample had been taken from the center of each circular plot, and the presence of specific vascular plant species within these circular plots was noted. These plots had 54 vascular plant species in common with our study plots, which occurred on at least five of the 736 plots. For each of these 54 species, a species $\mathrm{H}^{+}$ concentration was calculated using the mean of the $\mathrm{H}^{+}$concentrations from the plots where they occurred. The mean $\mathrm{H}^{+}$concentration value for each species was then used to calculate the community 
Table 2. Spearman's Rank Correlation Coefficients for the Relationships between Topographic Wetness Index (TWI), Mean Groundwater Level $\left(\mathrm{GW}_{\text {mean }}\right)$, Groundwater Level in September $2001\left(\mathrm{GW}_{\text {Sept }}\right)$, community $\mathrm{H}^{+}$Concentration $\left(\mathrm{H}^{+}\right.$conc), and Species Number on the $200-\mathrm{m}^{2}$ Level (SpN)

\begin{tabular}{llllll}
\hline & TWI & GW $_{\text {mean }}$ & $\mathrm{GW}_{\text {Sept }}$ & $\mathrm{H}^{+}$conc & SpN \\
\hline TWI & 1 & $0.47^{*}$ & $0.53^{* *}$ & $-0.37^{*}$ & $0.47^{*}$ \\
GW & 1 & $0.94^{* *}$ & $-0.50^{* *}$ & $0.52^{* *}$ \\
GW $_{\text {Sept }}$ & & & 1 & $-0.51^{* *}$ & $0.55^{* *}$ \\
$\mathrm{H}^{+}$conc & & & 1 & $-0.84^{* *}$ \\
SpN & & & & & 1
\end{tabular}

Data include only the plots where the groundwater-measuring tube could be inserted to a depth of $0.7 m$ or where water could be recorded. $n=50$. ${ }^{*} P<0.01$

$* * P<0.001$

$\mathrm{H}^{+}$concentration value (mean value of all species' mean $\mathrm{H}^{+}$concentration values within each plot) for each of the eighty-eight $200-\mathrm{m}^{2}$ plots in our study. The relationship between species numbers and both the community $\mathrm{H}^{+}$concentration and its standard deviation was analyzed using linear leastsquare regression.

\section{RESUlTS}

The correlation between distance to groundwater level in September 2001 and TWI was statistically significant and stronger than for mean groundwater level (Table 2). Therefore, we used the September measurements for further analyses. This correlation must be interpreted as an approximate measure of the ability of the TWI to predict groundwater levels because levels could not be measured in many plots. The correlation between distance to groundwater level and community $\mathrm{H}^{+}$ concentration was significant but slightly weaker. The correlation between TWI and community $\mathrm{H}^{+}$ was also statistically significant but not very strong (Table 2). The strength of the latter correlation increased using the larger dataset $\left(r_{\mathrm{s}}=-0.51,<P\right.$ $0.001, n=88)$. These negative correlations were caused by an increase in the number of species restricted to soils with lower $\mathrm{H}^{+}$concentrations (higher pH values) with TWI, which is shown by the within-plots standard deviation of the species $\mathrm{H}^{+}$concentrations increasing with TWI $\left(r_{s}=0.39, P\right.$ $<0.001, n=88$ ). For species numbers in the 200$\mathrm{m}^{2}$ plots, the correlation coefficient increases from TWI $\left(r_{\mathrm{s}}=0.47\right)$ to groundwater level in September $\left(r_{\mathrm{s}}=0.55\right)$ to being very strong for community $\mathrm{H}^{+}$ concentration $\left(r_{\mathrm{s}}=-0.84\right)$ (Table 2$)$.

Using least-square regression, we found a significant positive relationship between species numbers and TWI for all plot sizes, but the rela- tionship was strongest for the $200-\mathrm{m}^{2}$ plots $\left(200 \mathrm{~m}^{2}\right.$ : $R^{2}=0.30 ; 1 \mathrm{~m}^{2}: R^{2}=0.18 ; 0.25 \mathrm{~m}^{2}: R^{2}=0.20 ; 0.01$ $\mathrm{m}^{2}: R^{2}=0.13$; for all scales: $P<0.001, n=88$ ) (Figure 3 ). We also tested for quadratic relationships between species numbers and TWI, but the quadratic term $\left(\mathrm{TWI}^{2}\right)$ did not significantly improve the fit on any of the four scales (for the linear relationship: $P>0.05$, lack-of-fit test). As expected, the model explained less of the variation when using the lower, $50 \mathrm{~m}$ pixel, resolution $\left(R^{2}=0.20, P\right.$ $<0.001, n=88$ for the $200-\mathrm{m}^{2}$ plots).

For the largest plots, LOWESS regressions indicated that species numbers increased with TWI up to 8.9. TWI explained as much of the variation in species number within this range as when using the full TWI gradient $\left(R^{2}=0.30, P<0.001, n=68\right.$, linear least square regression) (Figure 3 ). For TWI values higher than 8.9, we found no relationship between species numbers and TWI $\left(R^{2}=0.01\right.$, $P=0.68, n=20)$. For the $1.0-\mathrm{m}^{2}$ and $0.25-\mathrm{m}^{2}$ plots (Figure 3B), species numbers increased with TWI up to 8.7 in the LOWESS models $\left(1 \mathrm{~m}^{2}: R^{2}=0.28\right.$, $P<0.001, n=67 ; 0.25 \mathrm{~m}^{2}: R^{2}=0.27, P<0.001$, $n=67$, linear least-square regression), thereafter decreasing with TWI $\left(1.0 \mathrm{~m}^{2}: R^{2}=0,29, P=0.012\right.$, $\left.n=21 ; 0.25 \mathrm{~m}^{2}: R^{2}=0.23, P=0.028, n=21\right)$. The same two localities for both the $0.25-\mathrm{m}^{2}$ and $1-\mathrm{m}^{2}$ plots caused this decrease (Figure 3B). Excluding these two plots resulted in a nonsignificant relationship to the right of the peak. One of these two localities had the highest TWI and the second highest total species number of all 88 plots on the $200-\mathrm{m}^{2}$ level. However, unvegetated boulders covered a large part of the plot, including the area of the subplots; thus, there were very low species numbers in the subplots. There was also a significant increase of species numbers with TWI on the $0.01-\mathrm{m}^{2}$ scale up to TWI $=8.4 \quad\left(R^{2}=0.16, \quad P=\right.$ $0.001, n=61$ ), but no relationship was found 

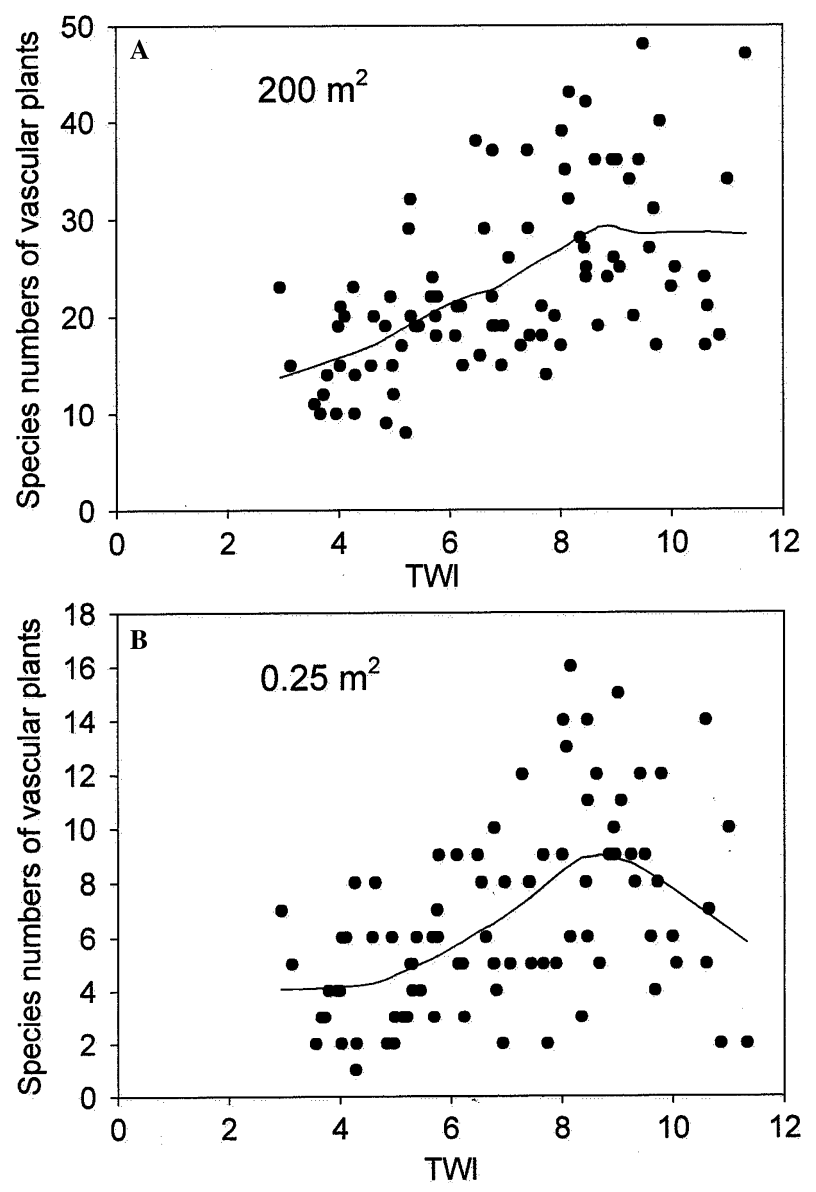

Figure 3. A Species numbers of vascular plants $\left(200-\mathrm{m}^{2}\right.$ plots) increased linearly with increasing wetness index up to TWI $=8.9\left(R^{2}=0.30, P<0.001, n=68\right.$, linear least-square regression), above which there was no relationship between species numbers and TWI. The curve was constructed using LOWESS regression (fraction of data points used for each regression $=50 \%$ ). On all 88 plots together, 116 species were found. B As in A for the $0.25-\mathrm{m}^{2}$ plots. Species numbers increased linearly up to TWI $=8.7\left(R^{2}=0.27, P<0.001, n=67\right)$, thereafter decreasing with TWI $\left(R^{2}=0.23, P=0.028, n=21\right)$. The observed pattern for the $1-\mathrm{m}^{2}$ plots was similar to $\mathbf{B}$, for the $0.01-\mathrm{m}^{2}$ plots, it was similar to $\mathbf{A}$.

above this level $\left(R^{2}=0.017, P=0.514, n=27\right)$. The relationships between species numbers and TWI were all stronger when we excluded the highest TWI values in the small plots $\left(0.001-\mathrm{lm}^{2}\right)$.

The set of eight $200-\mathrm{m}^{2}$ consecutive plots along the TWI gradient with the highest total number of species comprised 85 of the 116 species $(73 \%)$ (Figure 4A) within a TWI range of 8.03-8.46. The two most species-poor sets (each with $25 \%$, or 29 of the 116 species) had the lowest TWI ranges (Figure 4A). The eight most species-rich plots also included the highest number of regionally uncommon species (18 species, or $56 \%$ of the 32
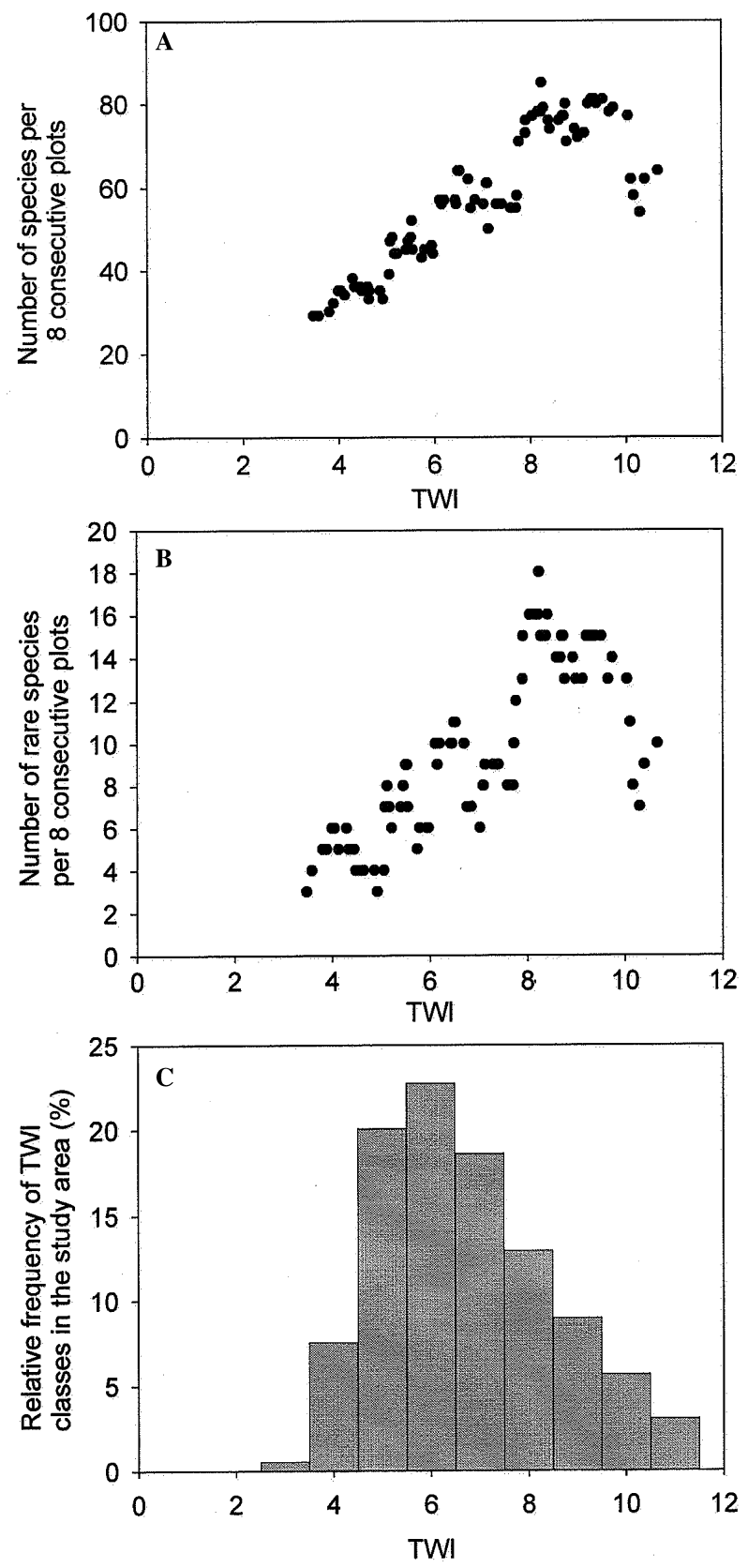

Figure 4. A Total number of different species in eight consecutive $200-\mathrm{m}^{2}$ plots along the TWI gradient, starting with plots $1-8,2-9$ and so on up to $81-88$. The plotted TWI of each group of eight plots represents the midpoint of the group's TWI range. B As in A but only including the 32 uncommon species [not classified as common in Krok and Almquist (2001)]. C Relative area (\%) of each TWI class. The TWI values were classified so that TWI of $2=1.50-2.49,3=2.50-3.49$, and so on. The calculations include areas within the TWI range 1.5-1 1.5. Note that species numbers are greatest in relatively uncommon TWI classes.

uncommon species found), whereas only three uncommon species were found in the most species- 
poor group (Figure 4B). Also, the proportion of regionally uncommon species in the $200-\mathrm{m}^{2}$ plots increased with TWI, up to TWI $=8.9\left(R^{2}=0.15, P\right.$ $<0.001, n=68$, linear least-square regression), thereafter decreasing with TWI $\left(R^{2}=0.20, P=\right.$ $0.047, n=20)$. The most common TWI class had relatively few species (For all and uncommon species), whereas the TWI classes with most species covered approximately $13 \%$ of and study area, excluding marshland and lakes (Figure 4C). We found a significantly nested pattern $(P<0.05)$, where none of the plant species occurred exclusively in the lower end of the TWI gradient (TWI 24,14 plots).

To examine whether the presence of peat, which indicates stagnant groundwater, affected the results, we excluded 12 sites with more than $50 \%$ peat cover (of more than $30 \mathrm{~cm}$ depth) at the 200$\mathrm{m}^{2}$ scale. The relationship between plant number and TWI remained almost unchanged; there was a positive linear relationship $\left(R^{2}=0.28, P<0.001\right.$, $n=62$ ) below TWI 8.9, and no relationship above $\left(R^{2}=0.02, P=0.615, n=14\right)$. In the multiple regression model constructed to predict species number, only altitude and basal area of $P$. sylvestris (in that order) were included in the model after TWI. This model explained another $8 \%$ of the variation in species number $\left(R^{2}=0.38, P<0.001\right.$, $n=88$ ) compared to the model including only TWI. The regression coefficient for altitude was positive, whereas it was negative for basal area of $P$. sylvestris (Table 1). Basal area of $P$. sylvestris had the strongest correlation with TWI $\left(r_{\mathrm{s}}=-0.46, P<0.001\right.$, $n=88$ ) but despite this, contributed significantly to the multiple regression model. Substrate number did not significantly contribute to the explanation of the variation in species number.

\section{DisCUSSION}

We found that most of the boreal forest landscape was relatively dry and species-poor, with TWI values less than 7.5, whereas interspersed patches linked to areas with relatively high TWI had species-rich vegetation (Figure 2-4), including the species of the drier parts of the forest landscape. Regionally uncommon species were disproportionately concentrated in these hotspots of plant species number (Figure 4B), further indicating special habitat conditions. The consistent pattern of increasing species numbers with TWI regardless of plot size indicates that this is a robust pattern in this landscape.

Data conformed with our hypothesis that the connection between species number and TWI is mediated in several steps. This wetness index predicts groundwater level, which affects soil factors (Giesler and others 1998), which in turn affects species numbers. Therefore, the correlation coefficient increased from TWI versus species number, to groundwater versus species number, to community $\mathrm{H}^{+}$concentrations versus species number (Table 2). This pattern is also illustrated by TWI being more strongly correlated to groundwater level than to $\mathrm{pH}$ and species number. The main shortcoming of TWI in this context seems to be its failure to predict areas of high soil $\mathrm{pH}$. This might have to do with the restricted ability, mentioned in the Methods section, of TWI to predict the mobility of the groundwater. However, compared to previous studies where topographic variables have been used to predict the variation in species number of vascular plants, the TWI is a good predictor, explaining $30 \%$ of the variation. For example, the model used by Hutchinson and others (1999) which explained $35 \%$ of the variation in species numbers, also included water-holding capacity of the soil in addition to topographic variables. There were also several nontopographic variables included in the model by Chipman and Johnson (2002), which explained $52 \%$ of the variation in species number. In the study by Nichols and others (1998), a single variable (soil drainage) explained $53 \%$ of the variation in species number, topographic variables contributed little. If surficial geology is heterogeneous and/or the landscape is flat, soil drainage may become more important than topography for the plant distribution patterns. In our study, the number of soil types did not add to the explanation of the variation in plant species numbers (Table 1). The soil in our study area was relatively homogeneous; if the plots were not peatdominated, we found mainly fine sandy till. Boulders were also common but bedrock was only found on five plots (Table 1).

The latest glaciation in Scandinavia left behind mainly till, except in areas temporarily covered by prestages of the Gulf of Bothnia, where sediments are frequently found. In this landscaps, almost entirely situated above the former highest coastline, topography therefore becomes more important than soil type.

We see three major explanations for the distribution pattern of species numbers. The first explanation is based on our observation that the proportion of species inhabiting soils with higher $\mathrm{pH}$ (lower $\mathrm{H}^{+}$concentrations) increased with TWI. The present Swedish flora originated mainly in southern Europe, where soil conditions are less acidic (Pärtel 2002). Glaciations have repeatedly 
destroyed the established vegetation of northern Sweden, paving the way for recolonization of plants from the south (Bennett 1997; Hewitt 2000; Willis and Whittaker 2000). Because the juvenile glacial till was generally base-rich, plant species requiring high $\mathrm{pH}$ could easily spread northward (Grubb 1987). In general, the till has been leached and has become more acidic since the latest glaciation, and where it does not consist of base-rich minerals, only small patches (such as discharge areas) offer benign conditions for plants growing in high-pH soils. This evolutionary history might explain why there are relatively few species that can withstand the acidic soil conditions currently dominating the boreal parts of Sweden, whereas many vascular plant species are restricted to patches of less-acidic soil.

Second, the positive correlation between the within-plot standard deviation of the species $\mathrm{H}^{+}$ concentrations and TWI indicates higher habitat heterogeneity within plots with higher TWI. In areas with low TWI values, most often the entire ground is dry and acidic; whereas in areas with high TWI values, there are often patches of drier and more acidic conditions-for example, on boulders, logs, and hummocks. The nested pattern for species occurrences along the TWI gradient shows that all species, including those typical of areas with low $\mathrm{pH}$ and low nutrient and water availability, grow in discharge areas, supporting the heterogeneity interpretation. Vascular plant species are mainly added to the overall species list along the increasing wetness gradient up to the optimal level. Few species are lost along the gradient.

Third, better nitrogen availability in areas with high soil-pH can affect species numbers. Giesler and others (1998) found a positive correlation between soil total nitrogen and soil $\mathrm{pH}$ along a moisture gradient in a forest area only $40 \mathrm{~km}$ from ours. It is well known that there is a positive correlation between soil nitrogen and $\mathrm{pH}$, as well as between these two edaphic variables and species numbers in the boreal forest (Cajander 1926). Thus, the negative relationship between species numbers and basal area of $P$. sylvestris could mirror nutrient availability, because $P$. sylvestris is well adapted to low-nutrient conditions.

The variation in species number unexplained by TWI can partly depend on the insufficient resolution of the digital elevation map. Small-scale topographic heterogeneity is not detected by the 20-m resolution, implying that the TWI does not reflect the details of groundwater movement in the area (Rodhe and Seibert 1999; Western and others 1999). Difficulties in finding the exact position of a site in the field may also add noise. For some plots with dense tree cover, the DGPS receiver showed position errors up to $8 \mathrm{~m}$, implying that parts of the $200-\mathrm{m}^{2}$ plots might have been situated in neighboring pixels with different TWI values. Undetected variation in the depth of the soil layer, origin and compactness of soil, and isolated occurrences of cation-rich bedrock intrusions are other factors that may play a role. Variation is also added by are competition, herbivory, and human land use (Western and others 1999).

In conclusion, the wetness index offers a tool to identify areas with high (and low) probability of having high species numbers and rarity of vascular plants [and potentially other organisms, for example bryophytes (Dynesius 2001)]. The correlation between TWI and local groundwater levels $\left(r_{s}=\right.$ 0.53 ) was as high as in previous studies (Moore and Thompson 1996; Lamb and others 1997; Seibert and others 1997). Compared with previous studies, the predictability of species numbers was good, given that the only input variable was topographyquantified without resource-demanding field investigations. Landscape assessment using the methods we describe here could precede decisions about forestry operations, road constructions, biodiversity surveys, and conservation management, or other activities that require finding and protecting spots with high species numbers and rarity. Note that because of the observed pattern of nestedness, protection of the most species-rich areas will cover most of the total species pool in this area. Last, but not least, the wetness index offers a comprehensive tool for further research into the processes governing plant distribution patterns on the landscape scale, knowledge that can be used to predict changes in species distributions related to global warming and the associated hydrologic alterations.

\section{ACKNOWLEDGMENTS}

The Lamm Foundation, the Foundation for Strategic Environmental Research (MISTRA), the Swedish Research Council for Environment, Agricultural Sciences and Spatial Planning (to C.N.), and the Swedish Research Council (to J.S.) funded the project. We thank Kenneth Holmström, Metria, for the interpretation of aerial photographs, and Johan Temnerud, Johanna Lindeberg, Åsa Laurell, Gunilla Nordenmark, Gunilla Nilsson, Per-Erik Wikberg, Göran Brorsson, Johanna Englund, Magnus Larsson, Elisabet Carlborg, Pia Hansson, Magnus Svedmark, and Per Herngren for fieldwork assistance. Kevin Bishop, Niclas Hjerdt, Hans Ivarsson, Roland Jansson, Edward A. Johnson, 
Bengt-Gunnar Jonsson, and two journal reviewers provided useful comments on the manuscript.

\section{REFERENCES}

Beers TW, Dress PE, Wensel LC. 1966. Aspect transformation in site productivity research. J For 64:691-2.

Bennett KD. 1997. Evolution and ecology: the pace of life Cambridge (UK): Cambridge University Press.

Beven KJ, Kirkby MJ. 1979. A physically based, variable contributing area model of basin hydrology. Hydrol Sci J 24:43-69.

Bishop K, Dambrine E. 1995. Localization of tree water uptake in Scots pipe and Norway spruce with hydrological tracers. Canadian J For Res 25:286-97.

Brualdi RA, Sanderson JG. 1999. Nested species subsets, gaps, and discrepancy. Oecologia 119:256-64.

Cajander AK. 1926. The theory of forest types. Acta For Fenn 29:1-108

Chipman SJ, Johnson EA. 2002. Understory vascular plant species diversity in the mixedwood boreal forest of western Canada. Ecol Appl 12:588-601.

Crawley MJ, Harral JE. 2001. Scale dependence in plant biodiversity. Science 291:864-8.

Dorner B, Lertzman K, Fall J. 2002. Landscape pattern in topographically complex landscapes: issues and techniques for analysis. Landscape Ecol 17:729-43.

Dynesius M. 2001. Spatial and evolutionary aspects of species diversity, species traits, and human impact with examples from boreal riparian and forest plant communities [dissertation]. Umeå, Sweden: Umeå University.

Ebeling F. 1978. Nordsvenska skogstyper. Sver Skogsvårds Tidsk 76:341-81.

Giesler R, Högberg M, Högberg P. 1998. Soil chemistry and plants in Fennoscandian boreal forest as exemplified by a local gradient. Ecology 79:119-37.

Grubb PJ. 1987. Global trends in species-richness in terrestrial vegetation: a view from the northern hemisphere. In: Gee JHR, Giller PS, Eds. Organization of communities past and present. Oxford (UK): Blackweil Scientific. p 98-118.

Heikkinen RK. 1991. Multivariate analysis of esker vegetation in southern Häme, S Finland. Ann Bot Fenn 28:201-24.

Hewitt G. 2000. The genetic legacy of the Quaternary ice ages. Nature 405:907-13.

Hjerdt KN, McDonell JJ, Seibert J, Rodhe A. 2004. A new topographic index to quantify downslope controls on local drainage water. Resour Res 40:W05602, doi: 10.1029/ 2004WR003130

Hutchinson TF, Boerner REJ, Iverson LR, Sutherland S, Sutherland KS. 1999. Landscape patterns of understory composition and richness across a moisture and nitrogen mineralization gradient in Ohio (U.S.A) Quercus forests. Plant Ecol 144:177-89.

Iverson LR, Dale ME, Scott CT, Prasad A. 1997. A GIS-derived integrated moisture index to predict forest composition and productivity of Ohio forests (U.S.A.). Landscape Ecol 12:33148.

Jonsson BG. 2001. A null model for randomization tests of nestedness in species assemblages. Oecologia 127:309-13.

Lamb R, Beven KJ, Myrabø S. 1997. Discharge and water table predictions using a generalized TOPMODEL formulation. Hydrol Proc 11:1145-67.
Krok TOBN, Almquist S. 2001. Svensk flora: fanerogamer och ormbunksväxter Stockholm: Liber Utbildning.

Moore ID, Grayson RB, Ladson AR. 1991. Digital terrain modelling: a review of hydrological, geomorphological, and biological applications. Hydrol Process 5:5-30.

Moore RD, Thompson JC. 1996. Are water table variations in a shallow forest soil consistent with the TOPMODEL concept? Water Resour Res 32:663-9.

Nichols WF, Killingbeck KT, August PV. 1998. The influence of geomorphological heterogeneity on biodiversity: II. A landscape perspective. Conserv Biol 12:371-9.

Økland RH, Eilertsen O. 1994. Canonical correspondence analysis with variation partitioning: some comments and an application. J Ve Sci 5:117-26.

O'Loughlin M. 1986. Prediction of surface saturation zones in natural catchments by topographic analysis. Water Resour Res 22:794-804

Ostendorf B, Reynolds JF. 1998. A model of arctic tundra vegetation derived from topographic gradients. Landscape Ecol 13:187-201.

Pärtel M. 2002. Local plant diversity patterns and evolutionary history at the regional scale. Ecology 83:2361-6.

Patterson B, Atmar W. 1986. Nested subsets and the structure of insular mammalian faunas and archipelagos. Biol J Linn Soc 28:65-82.

Quinn PF, Beven K, Chevallier P, Planchon O. 1991. The prediction of hillslope flow paths for distributed hydrological modelling using digital terrain models. Hydrol Process 5:59-79.

Quinn PF, Beven KJ, Lamb R. 1995. The $\ln (a / \tan \beta)$ index: how to calculate it and how to use it within the topmodel framework. Hydrol Process 9:161-82.

Rodhe A, Seibert J. 1999. Wetland occurrence in relation to topography: a test of topographic indices as moisture indicators. Agric For Meteorol 98-99:325-40.

Seibert J, Bishop K, Nyberg L. 1997. A test of TOPMODEL's ability to predict spatially distributed groundwater levels. Hydrol Proc 11:1131-44.

Skov F, Svenning JC. 2003. Predicting plant species richness in a managed forest. For Ecol Manag 180:583-93.

Stanford JA. 1997. Toward a robust water policy for the western USA: a synthesis of the science. In: Minckley WL, Ed. Aquatic ecosystem symposium: a report to the Western Water Policy Review Advisory Commission. Tempe (AZ): Arizona State University. p 79-84.

Tarboton DG. 1997. A new method for the determination of flow directions and upslope areas in grid digital elevation models. Water Resour Res 33:309-19.

Trexler JC, Travis J. 1993. Nontraditional regression analyses. Ecology 74:1629-37.

Western AW, Grayson RB, Blösehl G, Willgoose GR, McMahon TA. 1999. Observed spatial organization of soil moisture and its relation to terrain indices. Water Resour Res 35:797-810.

Whittaker RJ, Willis KJ, Field RJ. 2001. Scale and species richness: towards a general, hierarchical theory of species diversity. J Biogeogr 28:453-70.

Williams RN, Bisson PA, Bottom DL, Calvin LD, Coutant CC, Erho MW Jr, Frissell CA, others . 1999. Scientific issues in the restoration of salmonid fishes in the Columbia River. Fish Manag 24:10-9.

Willis KJ, Whittaker RJ. 2000. The refugial debate. Science 287:1406-7. 
Wolock DM, McCabe GJ. 1995. Comparison of single and multiple flow direction algorithms for computing topographic parameters in TOPMODEL. Water Resour Res 31:131524.

Wood EF, Sivapalan M, Beven K, Band L. 1988. Effects of spatial variability and scale with implications to hydrologic modeling. J Hydrol 102:29-47.
Yeakley JA, Swank WT, Swift LW, Hornberger GM, Shugart HH. 1998. Soil moisture gradients and controls on a southern Appalachian hillslope from drought through recharge. Hydrol Earth System Sci 2:41-9.

Zobel M. 1997. The relative role of species pools in determining plant species richness: an alternative explanation of species coexistence? TREE or Trends Ecol Evol 12:266-9. 